\title{
CNBP wt Allele
}

National Cancer Institute

\section{Source}

National Cancer Institute. CNBP wt Allele. NCI Thesaurus. Code C97889.

Human CNBP wild-type allele is located in the vicinity of $3 q 21$ and is approximately $16 \mathrm{~kb}$ in length. This allele, which encodes cellular nucleic acid-binding protein, plays a role in transcriptional regulation of sterol responsive genes. A four nucleotide repeat expansion in intron 1 resulting in 75 to 11000 CCT G repeats is associated with myotonic dystrophy type 2 . 